\title{
AUDIOVISUAL MEDIA INCREASES PREGNANT MOTHERS' KNOWLEDGE AND ATTITUDE OF HEPATITIS B DURING COVID-19 PANDEMIC
}

\author{
Indah Permadani, Rani Widiyanti Surya Atmaja, Diyah Sri Yuhandini \\ Poltekkes Kemenkes Tasikmalaya \\ indahpermadani2@gmail.com
}

\begin{abstract}
During pregnancy, mothers are at very high risk of getting infected with viruses, one of the viruses is hepatitis B. Hepatitis B is transmitted through horizontal and vertical ways. The knowledge deficit on pregnant mothers toward hepatitis B caused a lot of them to be infected with hepatitis B virus. One of solutions to increase their knowledge and attitude toward hepatitis B is by giving them health education with audiovisual media. The purpose of the study was to know if there was an impact of the health education with audiovisual media on the increase of pregnant mothers' knowledge and attitude toward hepatitis $\mathrm{B}$ in the working area of the Public Health Center of Waruroyom, Cirebon regency, in 2021. This research used quasi experimental methods which are pretest and posttest with control group design. Sample used in this research were 72 pregnant mothers obtained with the purposive sampling technique and the data collection used questionnaires. Based on the independent $\mathrm{t}$ test on the knowledge variable, the obtained result was $p$ value 0.00 whereas the obtained result on the attitude variable using mann-whitney was $p$ value 0.00 . Hence, there was an impact of education health with audiovisual media on the increase of pregnant mothers' knowledge and attitude toward hepatitis B. Audiovisual media can increase pregnant mothers' knowledge and attitude toward hepatitis B during Covid-19 Pandemic
\end{abstract}

Keywords: Audiovisual, Knowledge, Attitude, Pregnant mothers, Hepatitis B

\section{Introduction}

During pregnancy, mothers are at very high risk of getting infected with viruses, one of the viruses is hepatitis B which attacks the liver. In pregnancy, the risk of pregnant women getting Hepatitis B Virus (HBV) is actually similar to the risk of non-pregnant women getting the same disease at the same age, also this can happen in the third trimester of pregnancy. Pregnant mothers who have hepatitis B may gets 
risks such as abortion, premature birth and bleeding. (- \& Lestanti, 2018)

Horizontal transmission of HBV can be transmitted through percutaneous, mucous membrane or mucosa. Vertical transmission or Mother-To-Child-Transmission

(MTCT) will happen when a pregnant mother who has acute hepatitis B or who has a persistent HBV transmits the virus to the baby in her womb or the baby she has given birth to. HBV transmission can be divided into VHB in-utero transmission, perinatal transmission, and postnatal transmission (Gozali, 2020).

According to the World Health Organization (WHO), the viral hepatitis $\mathrm{B}$ and $\mathrm{C}$ viruses affected 325 million people worldwide leading to about 1.4 million deaths a year. It is the second major killer infectious disease after Tuberculosis (TBC), and 9 times more people are infected with hepatitis than Human Immunodeficiency Virus (HIV). Hepatitis can be prevented and treated even in hepatitis $\mathrm{C}$ case, it can be cured. However, most of the people living with hepatitis - over $80 \%$ - lack access to prevention, testing and treatment (WHO, 2019)
According to Riskesdas (2018), the hepatitis infection in Indonesia has an average prevalence of $0.4 \%$, where $1-5 \%$ are pregnant mothers who have hepatitis B (riskesdas, 2018). The total number of $\mathrm{HBs} A \mathrm{G}$ positive located in the working area of Puskesmas Waruroyom, Cirebon regency in 2019 were 7 cases and has grown as a result from January to October 2020 surpassing 17 cases of pregnant mothers having HBsAG positive (Dinkes, 2020).

With the new virus case, COVID-19, spreads so quickly both worldwide and in Indonesia, knowing no boundaries, can attack anyone without exception, including pregnant mothers and children. In this case, it caused the limitation of the access to provide health services especially antenatal care service for pregnant mothers

Health education is an application of education in health sector. Operationally, health education includes all activities of giving and increasing knowledge and attitude for individuals, groups or the public in order to maintain and improve their health (Notoatmodjo, 2012). By providing video media in delivering health education hopefully pregnant 
mothers' knowledge and attitude toward hepatitis B can be increased.

\section{Method}

This study uses a quantitative approach as the research method in the form of quasi experimental design (pretest and posttest with control group design).

The study took place in the working area of the Public Health Center of Waruroyom, Cirebon regency. It was conducted from August 2020 to March 2021. The population of pregnant mothers during the July to November period was 120 people. The sample size was 36 people for each group. The sampling method was purposive sampling, a form of nonprobability sampling.

The research instrument used a questionnaire taken by the previous researcher, Nugroho, F, F, (2019), modified by the researcher and had been tested for its validity and reliability consisting of 18 knowledge questions using Guttman scale with Yes or No answers. On the other hand, there were 19 questions about attitude taken from the previous researcher, Wulandari, (2017) and modified by the researcher using Likert scale.
Inclusion criteria of pregnant mothers who are able to read and write, are ready to become respondents, have gadgets and are able to access the internet, are at 1 st and 2 nd of trimester, and agree to join the survey until they finish. Exclusion criteria included pregnant mothers who did not complete the questionnaires. After answering the pretest questionnaires, continued by being given intervention, the interval between intervention to posttest questionnaires completion was 1 week and in each 2 days respondents were reminded to watch the video again which were sent through WhatsApp group. Bivariate analysis used Independent t-test for knowledge variable and Mann-Whitney for attitude variable getting help on the 21.0 version of SPSS program.

\section{Results}

Finding out the changes of knowledge before and after approach on the experimental and the control group, finding out the changes of attitude before and after approach on the experimental and the control group, finding out the changes of knowledge average before and after approach on the experimental and the control group, 


\section{DOI: $10.34305 /$ gemic.v1i1.316}

and finding out the changes of attitude average before and after approach on the experimental and the control group.
The normality test used the ShapiroWilk statistical test because the sample $<50$ (less than 50)

Table 1. The Changes in the Pregnant Women' Knowledge Toward Hepatitis B Before and After Being Given Health Education on the Experimental and the Control Group $(\mathbf{n}=36)$

\begin{tabular}{llcccc}
\hline Knowledge & \multicolumn{1}{c}{ Group } & $\begin{array}{c}\text { Average } \\
(\mathbf{s . b})\end{array}$ & $\begin{array}{c}\text { Difference } \\
(\mathbf{s . b})\end{array}$ & IK95\% & $\begin{array}{c}\boldsymbol{P} \\
\text { Value }\end{array}$ \\
\hline $\begin{array}{l}\text { Before audiovisual } \\
\text { media intervention }\end{array}$ & Experimental & $6,11(5,70)$ & $10,44(5,00)$ & $8,75-12,1$ & 0,000 \\
\hline $\begin{array}{l}\text { After audiovisual media } \\
\text { intervention }\end{array}$ & & $16,56(1,56)$ & & \\
\hline $\begin{array}{l}\text { Before leaflet } \\
\text { intervention }\end{array}$ & Control & $6,33(6,30)$ & $6,25(4,96)$ & $4,60-7,93$ & 0,000 \\
\hline After leaflet intervention & & $12,60(2,71)$ & & \\
\hline
\end{tabular}

The average of knowledge on both the experimental group and the control group before intervention were almost similar. After being given intervention, both groups had increase but the experimental group had bigger difference. While it was found out that both audiovisual media and leaflet had knowledge changes with $P$ value 0.00 .

Table 1. The Changes in the Pregnant Women' Attitude Toward Hepatitis B

Before and After Being Given Health Education on the Experimental and the Control Group $(\mathbf{n}=36)$

\begin{tabular}{lcccccc}
\hline \multicolumn{1}{c}{ Attitude } & Group & $\begin{array}{c}\text { Average } \\
(\mathbf{s . b})\end{array}$ & $\begin{array}{c}\text { Differen } \\
\text { ce (s.b) }\end{array}$ & IK95\% & $\begin{array}{c}\text { Median (Min- } \\
\text { Max) }\end{array}$ & $\begin{array}{c}\boldsymbol{P} \\
\text { Value }\end{array}$ \\
\hline $\begin{array}{l}\text { Before audiovisual } \\
\text { media intervention }\end{array}$ & eksperimen & $\begin{array}{c}58,11 \\
(6,30)\end{array}$ & $\begin{array}{c}10,47 \\
(5,70)\end{array}$ & $\begin{array}{c}8,54- \\
12,40\end{array}$ & - & 0,000 \\
\hline $\begin{array}{l}\text { After audiovisual } \\
\text { media intervention }\end{array}$ & & 68,58 & & & & \\
\hline $\begin{array}{l}\text { Before leaflet } \\
\text { intervention }\end{array}$ & Kontrol & - & - & - & 56,00 & 0,001 \\
\hline $\begin{array}{l}\text { After leaflet } \\
\text { intervention }\end{array}$ & & & & & $(49-71)$ & \\
\hline
\end{tabular}

The average of attitude on both the experimental group and the control group before intervention were almost similar. After being given intervention, there was an increase with 10,47 differences in the experimental group 
while the control group had 9 subjects' attitudes decreased, 4 stayed the same, and 23 increased. While it was found out that both audiovisual media and leaflet had attitude changes with $P$ value 0.00 .

Table 3. The Changes of Pregnant Mothers' Knowledge Average Toward Hepatitis B on Experimental and Control Groups

\begin{tabular}{lccc}
\hline \multicolumn{1}{c}{ Group } & Average (s.b) & $\begin{array}{c}\text { Average Difference } \\
\text { (IK95\%) }\end{array}$ & $\begin{array}{c}\boldsymbol{P} \\
\text { Value }\end{array}$ \\
\cline { 1 - 2 } Experimental & $10,44(5,00)$ & 3,57 & 0,000 \\
& & $(1,85-6,53)$ & \\
\hline Control & $6,25(4,96)$ & \multicolumn{2}{c}{} \\
\hline
\end{tabular}

There was average difference on the experimental and control groups with $P$ value 0.00

Table 3. The Changes of Pregnant Mothers'Attitude Average Toward Hepatitis B on Experimental and Control Groups

\begin{tabular}{|c|c|c|}
\hline Group & Median (Min-Max) & $P$ Value \\
\hline Experimental & $\begin{array}{l}10,50 \\
(0-22)\end{array}$ & 0,000 \\
\hline Control & $\begin{array}{c}2,00 \\
(-6-19)\end{array}$ & \\
\hline
\end{tabular}

There was average difference on the experimental and control groups with $P$ value 0.00

\section{Discussion}

The obtained analysis stated that there is an increase on the knowledge level of the pregnant mothers before and after having the health education that used both audiovisual media and leaflet with $p$ value 0.000 . This result is in line with the theory of Notoatmodjo, (2010) that one of the factors that can affect someone's level of knowledge is mass media or information.

The delivery of information in this research was conducted through health education where education health is an application of education in the health sector (Notoatmodjo, 2012). This result is in line with the theory of (Permatasari et al., 2017) who stated that there is a significant difference on 


\section{DOI: 10.34305/gemic.v1i1.316}

the knowledge level; between pretestposttest with $\mathrm{p}$ value $0,000(<0,05)$.

Meanwhile, for the attitude before and after the approach, the result also described that there were differences on the experimental and control group because of the $p$ value $<0,05$. According to Azwar (2013), one of the factors that can influence someone's attitude is mass media. In accordance with the $\mathbf{J}$ et al (2019)that there is an effect of health education with video media on the prevention of diarrhea disease with the $p$ value 0,000 .

The analysis result for the knowledge average difference on the experimental and control groups with $p$ value $<0,05$ therefore audiovisual media can increase the knowledge of pregnant mothers during Covid-19 pandemic compared with the leaflet media. The outcomes of health education gave significant impact on the increase of someone's level of knowledge. There were many ways to be done in giving health education to targets, one of the ways is through video. Based on the explained theory of Cahyo (2001) that Audio visual media is a supporting tool for eomeon to receive a message, so he or she can get useful knowledge and experiences to reach the goals and the targeted knowledge (in this case, it is the brain and memory practice). In line with the research of Jafar,S (2021) that there is an increase of knowledge and attitude toward the risk of hepatitis B before and after the approach of giving the health education using audiovisual media with $p$ value 0,000 or $<0,05$ on the knowledge variable, on contrary, the result of $p$ value on the attitude variable was 0,004 atau $<0,05$.

This study is not in line with the study conducted by Yuniwati (2019) declared that there is no difference on the average score on the level of knowledge among the audiovisual media group before and after intervention in which $p$ value 0,137 $<0,05$.

On the average difference of the pregnant mothers' attitude on the experimental and control group the $p$ value obtained was 0,000 atau $<0,05$ which means audiovisual media can increase pregnant mothers' attitude toward hepatitis $\mathrm{B}$, in comparison with the leaflet media. According to Notoatmodjo (2010) attitude was a reaction or response that is still closed from the stimulus. Or certain objects which involve related opinions and emotional factors (happy-unhappy, 
DOI: 10.34305/gemic.v1i1.316

agree-disagree, good-bad, like-dislike, and so on. In accordance with the theory. The researcher assumed that the use of video media was very different with other medias, because vidio has more understandable pictures and sounds. In line with the research conducted by Lisa et al (2020) that there is a significant change or difference between education through video media and leaflet media toward personal's hygiene attitude during teenager menstruation period $p$ value 0,000 that means wHo was rejected and He was accepted. While the attitude that obtains p 0,001 means Ho was rejected and Ha was accepted and the treatment's $p$ value 0,001 means Ho was rejected and Ja was accepted.

It is different with the other research that was done by Andriani, (2020) whose statement there was an impact of health education on the knowledge of school age children with $p$ value 0,025 and there was no impact of health education on the school age children's attitude as the $p$ value 0,510 toward dengue fever disease.

\section{Conclusion}

The conclusion is that the method of audiovisual media increased both pregnant mothers' knowledge and attitude during the Covid-19 pandemic in the Working Area of Waruroyom Public Health Center, Cirebon regency in 2021.

\section{Suggestion}

The suggestion for the public health center was to give online education health so the pregnant mothers would not miss any informations. Next, for the research in the future it is suggested that the study can develop media, appraisal and attitude.

\section{Reference}

-, R.-, \& Lestanti, D. M. (2018). Konseling Individual Dan Media Leaflet Meningkatkan Pengetahuan Ibu Hamil Tentang Hepatitis B Dalam Kehamilan Di Kelurahan Tanjung Ayun Sakti Wilayah Kerja Puskesmas Sei Jang Kota Tanjungpinang Tahun 2017. Photon: Jurnal Sain Dan Kesehatan, 9(1), 122-129. https://doi.org/10.37859/jp.v9i1.10 65

Azwar, S. (2013). Sikap Manusia: Teori dan Pengukurannya. Pustaka Pelajar. 
Cahyo, A. N. (2001). Berbagai Cara Latihan Otak dan Daya Ingat Dengan Menggunakan Ragam Media Audio Visual. DIVA Press.

Dinkes. (2020). Data Hepatitis B Ibu Hamil. Dinas Kesehatan.

Gozali, A. P. (2020). Diagnosis , Tatalaksana , dan Pencegahan Hepatitis B dalam Kehamilan. CDK Journal, 47(5), 354-358.

J, H., Oktavidiati, E., \& Astuti, D. (2019). Pengaruh Pendidikan Kesehatan Media Video dan Poster terhadap Pengetahuan dan Sikap Anak dalam Pencegahan Penyakit Diare. Jurnal Kesmas Asclepius, 1(1), 75-85. https://doi.org/10.31539/jka.v1i1.7 47

Jafar,S, R. (2021). Pendidikan Kesehatan Pada Remaja Tentang Faktor Risiko Berhubungan Penyakit Hepatitis B Dengan Media Video. Media Bina Ilmiah, 15.

http://ejurnal.binawakya.or.id/inde x.php/MBI

Lisa, L. H., Kurnaesih, E., \& Sundari. (2020). Pengaruh Edukasi Melalui Media Video Dan Leaflet Terhadap Perilaku Personal Hygiene Pada Masa Menstruasi Remaja Di SMPN 2 Toili Kec. Mailong Kab. Banggai. Journal of Aafiyah Health Research (JAHR), 1(1), 19-27. https://doi.org/10.52103/jahr.v1i1. 92

Notoatmodjo. (2010). Promosi Kesehatan dan Teori Aplikasi. Rineka Cipta.
Notoatmodjo. (2012). Pendidikan dan Perilaku Kesehatan. Rineka Cipta.

Nugroho, F, F, A. (2019). 'FaktorFaktor Yang Berhubungan Dengan Pengetahuan Ibu Hamil Tentang Hepatitis B Pada Ibu Hamil Di Puskesmas Kecamatan Cilincing [Poltekes jakarta 3]. http://repository.poltekkesjakarta3. ac.id/index.php?p=show_detail\&id $=1854 \&$ keywords $=$

Permatasari, A., rezal, F., \& Munandar, S. (2017). Efektifitas Media Audio Visual Dan Leaflet Terhadap Peningkatan Pengetahuan, Sikap Dan Tindakan Tentang Pencegahan Penyakit Gastritis Pada Santriwati Di Pondok Pesantren Hidayatullah Putri Dan Ummusshabri Kota Kendari Tahun 2017. Jurnal Ilmiah Mahasiswa Kesehatan Masyarakat Unsyiah, 2(6), 184073. https://doi.org/10.37887/jimkesmas

riskesdas. (2018). Laporan Nasional Riskesdas 2018. http://labdata.litbang.kemkes.go.id/ images/download/laporan/RKD/20 18/Laporan_Nasional_RKD2018_ FINAL.pdf

WHO. (2019). Hepatitis B. World Health Organization. https://www.who.int/campaigns/w orld-hepatitis-day/2019

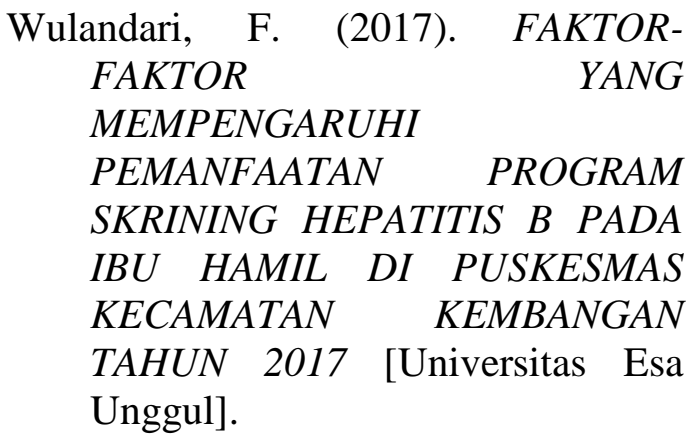


https://digilib.esaunggul.ac.id/fakto rfaktor-yang-mempengaruhipemanfaatan-program-skrininghepatitis-b-pada-ibu-hamil-dipuskesmas-kecamatan-kembangantahun-2017-9616.html

Yuniwati, C., Yusnaini, Y., \& Khatimah, K. (2019). Pengaruh Media Audio Visual Dan Media Leaflet Terhadap Tingkat Pengetahuan Remaja Mas Darul Ihsan Aceh Besar Tentang Hiv/Aids. Jurnal Ilmiah PANNMED (Pharmacist, Analyst, Nurse, Nutrition, Midwivery, Environment, Dentist), 13(2), 116120.

https://doi.org/10.36911/pannmed. v13i2.398 